\title{
CULTURAL ASPECTS OF ARMED CONFLICTS
}

\author{
Tadeusz Szczurek \\ Military University of Technology
}

\begin{abstract}
This article presents the problems of military operations in the context of the local culture, which is of essential importance to the conducted military actions. Despite the globalisation process, which, as it seems, blurs cultural differences, these differences still exist, and in many cases they even get deeper. This complex situation is also combined with conflicting interests of various state and non-state entities and social groups. A part of this image of the reality is the phenomenon of war, present from the beginning of the human civilisation. It should be noted that cultural differences are among the major causes of wars. Only for such a reason, the area of military operation becomes culturally alien at least for one of the parties to the conflict. We should also consider the operations conducted by international forces in different parts of the world, where often a multicultural military contingent operates in a culturally alien environment. These are particularly complex issues, which cannot be entirely explained, hence the scientific discussion presented below is merely an attempt to diagnose the most important problems without identifying specific solutions. Attention was paid to cultural factors affecting the sources of conflict and their developments and the cultural shape of the environment of military operations. Among the global phenomena, which determine the course of the future armed conflicts, the cultural transformation of society and the related tensions, global culture of trade, migration, mass communication and information technologies as well as the revival of religion and nationalism are mentioned. We should also bear in mind the local conditions, which include social, political, governance, assessment and evaluation, communicational and organisational aspects as well as the aspects of acceptance of autonomy by the parties to the conflict.
\end{abstract}

Keywords: culture, globalisation, military conflicts, military operations, war.

\section{War and civilisation in the historical perspective}

Cultural aspects are not the main subject of interest to researchers exploring the field of armed conflict, though they often appear in the background discussion of the phenomenon of war in terms of both historical and contemporary perspective. Most often the phenomenon of war is the subject of research by historians, which seems to be obvious, given the incidence of wars in the history of mankind. Today we can find more and more publications related to the armed conflicts in the context of events in the world of science, technology, medicine and law. It is impossible not to mention philosophers and cultural theorists among those interested in this field, especially because every conflict is usually firmly rooted in specific cultural realities. And the culture itself has a more or less direct impact on the safety of the given society, because it is a "dynamic system of rules, explicit and implicit, established by groups in order to ensure their survival, involving attitudes, values, beliefs, norms, and behaviors, shared by a group but harbored differently by each specific 
unit within the group, communicated across generations, relatively stable but with the potential to change across time"1.

Dominik Strasburger called wars the diseases, ongoing across the continents since the dawn of the civilisation. In his opinion, the wars resulted in disability and loss of life, transformation in culture and political changes ${ }^{2}$. Aristotle compared the war to the art of hunting, which served the acquisition of vital resources, and Heraclitus spoke of war as the king of all things, which makes one a slave and another a lord ${ }^{3}$.

A man waging war is a very complex phenomenon. Often he does not fight for material goods, but rather for an idea, as evidenced by the example of Arab followers of Muhammad, which have been pushed to war for desire to promote faith. Alexander of Macedon felt satisfied as ruler of the Greek cities, but he plundered the Persians, as it seems, for the pleasure of looting for its own sake. The Mongols, who had made even greater conquests, did nothing to consolidate the fruits of their victories. Timur, a Tartar claiming himself to be a descendant of Genghis Khan, probably did not value the lands he conquered at all - "fell on them like a vulture and left them, when he satiated appetite" 4 .

Hugo Kołłątaj, one of the greatest thinkers of the Polish Enlightenment, tried to understand history of wars for the purpose of subordinating weaker countries by the stronger ones, seizure of their wealth and territories, forcing conquered peoples to work for them. He wondered why the war has become a permanent phenomenon in the history of the mankind5. In his view, the source of war lies in the "accidental society", in which people could not make any agreement because: a concern for the particular interests had smothered the sense of universal values and common laws of nature; than a differentiation of human endeavours appeared, there were different and even conflicting moral norms, the beliefs and ways of governance differentiated ${ }^{6}$.

According to Zygmunt Wasilewski, the war is the result of a natural tendency of a stronger civilisation to achieve dominance over a weaker civilisation. Wasilewski thought that the mere fact of existence of different cultures raised conflicts 7 .

The correlation of phenomenon of war with the natural expansiveness of civilisations was also pointed out by Feliks Koneczny. In his opinion, pacifist ideologies

1 D. Matsumoto, L. Juang, Psychologia międzykulturowa, GWP, Gdańsk 2007, p. 198 (Culture and Subjective Well-being, MIT Press, 2000).

2 Cf.: D. Strasburger, Zasady sztuki wojennej, Warszawa 1996.

3 J. Świniarski, Przemiany myślenia o wojnie i wojsku, [in:] „Wojsko i Wychowanie” 1998, Issue 7, p. 44.

4 J. Keegan, Historia wojen, Warszawa 1998 (Keegan, A History of Warfare, 1994), p. 84.

5 R. Rosa, L. Wyszczelski, Wojna i pokój w polskiej myśli społecznej i wojskowej, Warszawa 1996, pp. 23-24.

6 Z. Kuderowicz, Polska filozofia pokoju. Historia idei pokoju w kulturze polskiej do 1939 roku, Warszawa 1992, p. 82.

7 L. Gawor, Katastrofizm w życiu cywilizacji narodowych wedtug Zygmunta Wasilewskiego, [in:] A. Żuk (ed.), Konflikt i walka, Lublin 1996, pp. 31-43. 
are merely an "illusion" of eternal and universal peace, in view of the fact that there is a law of history saying that stronger civilisations fight in contact with each other; they must fight one another. War can be avoided only if this natural expansiveness can be satisfied with other measures, such as economic or ideological ones ${ }^{8}$.

Cultural differences, most commonly associated with the professed faith, had always been and probably will always be the source of misunderstandings, tensions, conflicts and even wars. Christian nations often were forced to conduct wars to defend their own culture, sovereignty of their states and sometimes even to defend their biological being. Not to fight against the invaders would mean annihilation of the nation and the whole Christian culture9.

\section{Multiculturalism in the face of globalisation}

Civilisation differences shaped over the centuries are firmly rooted in the culture and religion and nowadays collide with the omnipresent globalisation. According to Andrzej Targowski, in the 21 st century there are eight "vertical" civilisations oriented by religions (Chinese, Buddhist, Eastern, Islamic, Japanese, African, Western and Indian) and one "horizontal" civilisation, that is, the Global Civilization ${ }^{10}$. Political power based on geography, in particular related to a specific territory, is also subject to these processes. Globalisation allows people to go beyond a specific area, there are no borders ${ }^{11}$. The phenomenon of rapidly growing interdependence between different, even the most remote parts of the world can be described most simply and most accurately by the term globalisation.

The essence of globalisation processes should be considered primarily in two dimensions of social and individual life. These dimensions are: space and time. Shorter time needed to overcome a significant distance and instant communication (text, voice, video) make these distances seem shorter, so the world may seem smaller ${ }^{12}$. Hence the popular saying "global village"13. Every year the process of globalization

8 F. Koneczny, Prawa dziejowe, Londyn 1982 (History laws (and bonus) German byzaninism, Towarzystwo im. Romana Dmowskiego, London 1982), p. 165.

9 Cf. T. Szczurek, Konflikty zbrojne. Problematyka filozoficzno-moralna, Wydawnictwo WAT, Warszawa 2009, pp. 9-58.

${ }^{10} \mathrm{R}$. Jakubczak, J. Flis (ed.), Bezpieczeństwo narodowe Polski w XXI wieku. Wyzwania istrategie, Bellona, Warszawa 2006, p. 76.

${ }^{11} \mathrm{~J}$. Norberg, Spór o globalizację. Kto zyskuje, kto traci, ile i dlaczego, Wydawnictwo Fijorr Publishing, Warszawa 2006 (In Defense of Global Capitalism, Cato Institute 2003), p. 7.

${ }^{12}$ Szanse i zagrożenia rozwojowe $w$ warunkach społeczeństwa informacyjnego, collective work by the team of authors: P. Sienkiewicz, T. Jemioło, L. Zacher, M. Jóźwiak, H. Świeboda, Akademia Obrony Narodowej, Warszawa 2001, p. 130.

${ }^{13}$ The term "global village" has been invented and promoted by Marshall McLuhan in his book: M. McLuhan, The Gutenberg galaxy: the making of typographic man, University of Toronto Press, Toronto 1965. 
involves more and more new areas of life and new geographical regions. Goods, capital, information, and finally people move in the international environment with increasing intensity. The borders of nation states are more and more open, their sovereignty is subject to systematic erosion. External factors have increasing impact on the internal situation and lives of people across different countries ${ }^{14}$.

In view of Kazimierz Kuciński the globalisation means the global integration of economic systems and economic actors. It consists in that economic activity is coordinated in the whole world scale in order to minimise costs, to maximise new, that is, added value of the products and to gain access to the global market. Economic globalisation results in a globalisation of all the aspects of social life: technology, lifestyle, consumer models, culture, governance, legislation and human consciousness. It results from the compression of the world achieved through technological development and unification of forms of organisation of the economy and political life in various countries as well as from the common belief that our globe is a "Spaceship Earth"15. Of course, not all perceive a globalisation as a rapid process of formation of a unified world. It is shown by the huge disparities in the development of the regions and the living standards of the population - "in the globalising world we have to deal with the problem of obesity and all the consequences of this phenomenon, but also a permanent problem of hunger, [...] part of the world is struggling with addiction to media, but residents of another part of the world during their entire lives have not seen any medium with their eyes and are not going to see any for a long time"16. Not everywhere the globalisation processes have the same force. Globalisation reaches some regions very late, and some of them even defend against globalisation. The communication techniques are among the least discussable and the most often mentioned driving forces of globalisation. They allow fast movement of people, goods, services, capital and technology and downright instant flow of information ${ }^{17}$.

A contemporary picture of the society was formed over the whole history of our civilisation. Janusz Świniarski stresses that civilisation waves overlap like waves of the sea. There is no higher wave without a lower wave, therefore there is no wave of knowledge and information without a lower wave, which is a wave of preference to the land, place and agricultural crops. Without land and farms there is no mass production. And finally, no land and no mass production means

\footnotetext{
${ }^{14}$ W. Anioł, Procesy globalizacyjne we wspótczesnym świecie, [in:] K.A. Wojtaszczyk, W. Jakubowski (ed.), Społeczeństwo i polityka. Podstawy nauk politycznych, Wydawnictwo Oficyna Wydawnicza ASPRA JR, Warszawa 2005, p. 801.

${ }^{15}$ K. Kuciński, Gospodarka globalna, Wydawnictwo KURPISZ, Poznań 2000, p. 13.

${ }^{16}$ U. Kusio, Globalizacja jako imperatyw zmiany na skali wartości rdzennych, [in:] A. Maksymowicz (ed.), Moralne dylematy Polaków w ponowoczesności, Zakład Wydawniczy NOMOS, Kraków 2009, p. 322 .

17 Ibidem.
} 
no information society. The superiority of knowledge and information society consists in managing the resources such as land, farm and production, in a more efficient manner, avoiding waste of human activity and pushing it toward a broader efficiency understood as the effectiveness, which brings the development and progress, both today and in the future ${ }^{18}$.

Sample benefits of globalisation include: 1) free flow of information, people and capital as well as possibility of introducing single currency, 2) easier access to markets and new prospective of economic development, 3) transfer of modern technologies, including those friendly to the environment, and increased opportunity to use technologies developed by others, 4) development of international cooperation and growing importance of transnational legal standards, 5) possibility of joint action for the protection of the environment and solving global environmental problems, 6) growing sense of community and development of cosmopolitan personality, 7) increasing chance to ensure world peace ${ }^{19}$. On the other hand, there are some risks arising from globalisation, which include: 1 ) information chaos, the plethora of unnecessary information, 2) uncontrolled migration of people, 3) growing power of powerful industrial conglomerates and decreasing chances of small businesses, 4) growing power of transnational corporations, including major financial institutions, 5) growing scale of the exploitation of poor countries by rich countries, 6) increased pace of environmental degradation ${ }^{20}, 7$ ) xenophobia, associated with the prospect of losing part of the autonomy and independence, 8) weakened national identity, "contamination" of national languages, 9) blurring the boundaries of culture, loss of national, regional and local culture and tradition. According to Zygmunt Bauman, the process of globalisation, particularly mass communication, in fact, it promotes international cultural pluralism. It greatly facilitates instilling national culture through a public national education system managed by the state as well as participation in the political culture formed this way; it also promotes differences in national cultures. So the processes of globalisation, being far from reducing nationalism and abolition of national structures, in fact, broaden this impact, promote greater mobilisation of peoples and improve their "distinctive character"21.

In a globalised world, our imagination is more and more formed by the media, which dictate the style of contemporary culture, and thus have an influence

${ }^{18}$ J. Świniarski, Zastosowanie megatrendów cywilizacji, wiedzy i informacji w etyce biznesu, [in:] J. Jaroń, Ekofilozofia, bioetyka, etyka biznesu. Aktualne problemy współczesności, Wydawnictwo Akademii Podlaskiej, Siedlce 2004, p. 170.

${ }^{19}$ K. Kuciński, Gospodarka globalna..., op. cit., pp. 159.

${ }^{20}$ More about the environmental risks: A. Bikowski (ed.), Globalizacja gospodarki a ochrona środowiska, Szkoła Główna Handlowa, Warszawa 2002; E. Kośnicki, Człowiek wobec procesów globalizacyjnych, [in:] Z. Hull, W. Tulibacki (ed.), Człowiek wobec świata, Polskie Towarzystwo Filozoficzne, Olsztyn 1996, pp. 151-166.

${ }^{21}$ Z. Baumann, Nacjonalizm, Sic!, Warszawa, 2003, pp. 178-179. 
on a public perception of various events, including the situation in the theatre of military operations, which, consequently, indirectly determines their range and the manner, in which they are conducted. Image of military operations is transmitted in real time, and social networks or media portals are places, where public opinion is shaped. Military operations often reflect a global dynamism. Fast military response to local conflicts and their multinational character can be seen in most military operations in recent years.

Globalisation does not resolve any disputes between countries, social or political problems between members of the local communities, indeed it paradoxically makes nationalism much stronger and religious or ethnic disputes destabilise the situation of several countries in the region. It also leads to a slow erosion of the importance of countries in the sphere of international relationships. Traditional borders between the countries are disappearing, putting a question mark over their sovereignty. There is a growing importance of non-state actors in global relationships. Traditionally understood, classical wars between states are a less and less common phenomenon. Modern states and international organisations decide on use of military forces primarily for humanitarian reasons or for the purpose of a broadly meant struggle for peace.

It is difficult to predict the impact of globalisation on the cultural picture of the future world and of global security. The globalisation process brings many challenges, which are both opportunities and threats to security. Whole regions, countries and social groups can slide into economic stagnation, political instability and cultural alienation. This may lead to political, ethnic, ideological and religious extremism. Major problem of the future are possible conflicts erupting on religious, ethnic and cultural backgrounds. Failure to understand the processes taking place in the modern world, intolerance and missed opportunities stemming from globalisation can lead to many new ethnic, ideological and religious conflicts 22 .

It cam be concluded that globalisation is a process, in which various forms influencing today's environment of military operations exists and develop, and its transnational nature supports the independence of individual social groups from the state, in which they exist. Therefore, it becomes necessary to understand the cultural changes and conflicts in the context of military operations, not only in terms of the region, where a military action is carried out, but also in a broader context ${ }^{23}$.

22 Szanse i zagrożenia rozwojowe w warunkach społeczeństwa informacyjnego, op. cit., Warszawa 2001, pp. 131-132.

${ }^{23}$ Cf.: T. Szczurek, Od deskrypcji do antycypacji wykorzystania potencjału militarnego w kształtowaniu bezpieczeństwa nowoczesnych wspólnot państwowych wobec rozwoju zagrożeń niemilitarnych, Wydawnictwo WAT, Warszawa 2012, pp. 42-61. 


\section{Cultural aspects of military operations}

The way of waging a war has always been, is, and probably will be determined by the culture of the warring parties, since the culture is composed by religion, language, literature, arts, traditions, customs, laws, social organisation, production technology, economic exchange as well as philosophy and science ${ }^{24}$. Most of these elements have a significant impact on visible and invisible image of the armed conflict, as it is comprehensively discussed, among others, by Marek Pawlak from the National Defence Academy ${ }^{25}$.

Culture is a complex of factors and forces, which determine phenomena and processes of social life. In the interpersonal interaction, knowledge of the culture of the community allows us to understand and predict the behaviour and actions of its members. In analysing the context of military operations, it is necessary to take into account the multiculturalism of the modern world. The world has always been multicultural and, looking from a historical point of view, today's multiculturalism is poorer than that from the centuries ago, because many cultures do no longer physically exist, and the globalisation described in the previous section rather blurs than promotes the differences. Cultural resources as natural resources are constantly shrinking ${ }^{26}$.

Multiculturalism has always been and is a way of ordering and organising the world of human intentionality, which is diverse in terms of symbolic conventions. The concept of multiculturalism assumes that cultures are always in the plural, that they are somehow quantified beings, usually also associated with a specific location of a group of its carriers in time and space. Culture is losing its rootedness in a particular territory, and multiculturalism means we experience it every day in a crowd of people, who move in a common transit space. Trends described above are known as the concept of culture deterritorialisation.

The region of military operation is shaped by many factors, which interact in different dimensions. These are trends related to global cultural processes, having local impact on raise and persistence of conflicts between states, ethnic groups, clans, tribes, religions or civilisations. We cannot forget here about the deep-rooted ties between local communities. For example: "ethnic diversity and multiculturalism make it impossible for Afghanistan to think of collective cultural identity. Instead, we can see clusters of local communities identifying with their own cultures, ethnic groups and national minorities. Lack of a common, well-established cultural denominator is a possible hazard of socio-political conflicts inside the country. Hazaras, Tajiks, Turkmens, Uzbeks, Nuristanis and other people, when asked about their

\footnotetext{
${ }^{24}$ F. Znaniecki, Nauka o kulturze, Warszawa 1971, p. 44.

${ }^{25}$ M. Pawlak, Czynniki determinujace działania militarne wśrodowisku zróżnicowanym kulturowo, doctoral dissertation, promoter M. Wrzosek, Akademia Obrony Narodowej, Warszawa 2013.

${ }^{26}$ W.J. Burszta, Świat jako więzienie kultury, Warszawa 2008, p. 43.
} 
nationality, in the first place mention the name of their ethnic group, and only then define themselves as Afghans"27.

Marek Pawlak suggests that it is worth referring to examples from recent years in search of explaining cultural aspects of warfare. Huge concentration of cultural factors influencing the course of the conflict could be seen in the former Yugoslavia. The main parties to the conflict were the Croatian population, living in Croatia, and the Croatian Serbs. In Bosnia and Herzegovina the Bosnian government fought with the Bosnian Serbs and Croats, who also fought among each other. A secondary participant was Serbian government supporting compatriots in Bosnia and Croatia. Tertiary participants were: on the part of Croatia: Germany, Austria and the United States, on the part of Serbia - Orthodox countries, and on the part of Bosnian Muslims - Islamic countries. Russian nationalists and Orthodox hierarchs did not hide their support for Serbia, their contempt for the Bosnian "Turks" and criticism of Western and NATO imperialism. Nationalists in Russia and Serbia jointly acted to raise an objection against a Western "new global order" in both countries. These sentiments became very popular among the Russians. Every second resident of Moscow was opposing the NATO air raids in the summer of 1995. Russian nationalist groups successfully recruited young Russians to fight for the cause of "Slavic brotherhood". The biggest commotion occurred in the Islamic world in support of the Bosnian Muslims. The support for Bosnians came from many sources, both private and public ones. Governments, especially Iran and Saudi Arabia, Sunni and Shia fundamentalists and lay people supported the Bosnians diplomatically and humanely, but they also organised a military support.

The war in Bosnia was a war of civilisations. The three main participants came from three different cultures and professed different religions. The Croats declared themselves a noble vanguard of the West, confronting Orthodoxy and Islam. Serbs identified their enemies with "Islamic fundamentalists" threatening the Christianity for centuries. In turn, the Bosnian Muslims identified themselves as victims of genocide, whose fate is indifferent to the West due to different religion, therefore they deserved help of the Islamic world. All participants in the Yugoslavian wars considered them the conflicts of religious or ethnic-religious origin. This was also the opinion of most observers. The conflicts had become religious fights between three great world religions: Catholicism, Orthodoxy and Islam, the remains of the empires that once bordered with each other in Bosnia ${ }^{28}$. If we look at the secondary and tertiary participants of this conflict, we would see that their composition reflected, to a large extent, their civilisation model. The Orthodox countries and organisations

${ }^{27}$ A. Czupryński, L. Elak, H. Schreiber, Bezpieczeństwo dla rozwoju. Komunikacja międzykulturowa w operacjach reagowania kryzysowego, Akademia Obrony Narodowej, Warszawa 2012, p. 113.

${ }^{28}$ K. Mojzes, Yugoslavian Inferno, "New York Times" 17.09.1992, pp. 29-30 and M. Glenny, Carnage in Bosnia, for Starters, "New York Times", 29.07.1993, p. 23. 
supported Serbs against Croats and Muslims. Governments and the elite of the West supported the Croats, manifested a condemning attitude towards Serbs and a neutral or distrustful attitude towards the Muslims. A deviation from this civilisation pattern turned to be the United States, because the leaders of this country in their speeches talked on the side of Muslims. As the war prolonged, divisions and hatred between the warring groups got deeper and deeper and their religious and civilisation identity grew stronger. This was especially true for Muslims. Some lessons can be drawn from the war in Bosnia, which with caution can be considered general regularities. Firstly, the main participants in the conflicts on the border lines can count on help, sometimes very significant, from civilisational brothers. Secondly, this support can greatly influence the course of the war. Thirdly, the Governments and the peoples of one civilization are not willing to spend their blood or money for people from a different cultural circle. In the latter case, however, there are the situations, where wealthy countries or international organisations engage in help, usually a material aid, to the victims, regardless of their cultural or religious affiliation.

The impact of cultural factors, characterising a given society, on activity in the area of military strategy has been shown in an interesting way in the analysis of the impact of cultural factors carried out by Dim Adamski ${ }^{29}$ within the RMA concept. The author based his reflections on the example of the armed forces of Russia, the United States and Israel. The origins of the theory of RMA date back to the 80s of the last century. Strategic discussion was based on the use of the so-called Technical Military Revolution. One of the impulses to this discussion was the defeat of Arabian countries in the war with Israel, when the quantitative superiority on the part of Arab countries was compensated by technology, including radar systems and systems for precise targeting. Then the picture the future battlefield appeared, where a dominant role should be played by the highly advanced technology of weapons and information systems ${ }^{30}$. Generally speaking: the RMA concept is a theory defining the future of military operations, often associated with technological and organisational recommendations. If the operation concerns a culturally alien area, its effectiveness will be largely dependent on the level of knowledge of this territory. The higher competence related to its culture heritage, the greater the effectiveness of the operation. In such an environment also the capabilities to carry out the military operations will be achieved faster.

The above discussion suggest determining cultural factors, which impact on raise, persistence, prolongation and recurrence of conflict situations and on development of context of military operations. We should consider the factors such as: existential, social and political governance, assessment and evaluation, communicational and

${ }^{29}$ Revolution in Military Affairs.

${ }^{30}$ Vide: Ł. Kamieński, Technologia i wojna przyszłości, Wydawnictwo Uniwersytetu Jagiellońskiego, Kraków 2009. 
organisational aspects as well as the aspects of acceptance of autonomy. Among the global phenomena, which determine the course of the future armed conflicts, we should mention transformation of societies and the related tensions, global culture of trade, migration, mass communication and information technologies as well as the revival of religion and nationalism. In political dimension of social life, the context of military action determines, how power and leadership is distributed in a specific cultural circle, as well as the behavioural and influential patterns. These structures, as in case local governments, can be organised in various forms, from the most primitive ones, such as tribes, up to the well organised state structures. In many cases, the governance system is determined by traditions and customs, but also by the affiliation or social origin. Similarly in the local dimension, they determine, how power and leadership is distributed in a specific cultural circle, as well as the behavioural and influential patterns. Dimension of social relationships is characterised by the fact that the subjects and the objects of a specific action are people, their relationships, roles, arrangements and social processes taking place in the internal and external relationships. Factors affecting these interactions are age, national origin, ethnicity, confessed religion and gender, and these norms are developed through history, represented in customs and traditions; they express the manner, in which the community communicates verbally and non-verbally, in language and communication channels, intonation or importance of context and traditions and customs. The economic dimension includes activities and technical products associated with the production, distribution and services to meet the natural needs of man, making differences in the social relationships, which constitute the exchange network. Not every society bases its relationships on money, and some regulations stem from religion. In addition, each society or cultural circle has different exchange systems based on legal or not legal systems and establishes its own system of distribution of wealth. And, finally, we should mention a very important symbolic and cultural dimension, which determines context of the operation. These are the factors, based on which a given community evaluates and assesses the surrounding reality through the prism of its stereotypes, prejudices, holistic, transcendental and dialectical thinking as well as the traditions and customs. We are dealing here with folklore, symbols or events or individuals of symbolic significance as well as with historical experience, norms or taboos. All these factors overlap, making a defined context, which has a significant impact on the potential military action ${ }^{31}$.

In conclusion, we can say that cultural factors affect the raise and persistence of today's conflicts between countries, ethnic groups, clans or tribes, and, at the same time, the globalisation, transnational nature of the ongoing changes and multiculturalism of the modern world determine the context of the region of a military

${ }^{31}$ M. Pawlak, Czynniki determinujące prowadzenie działań militarnych..., op. cit., pp. 95-96. 
operation. The risk of escalation of the conflict can be minimised through continuous communication with the parties to the conflict. Therefore, communication and negotiation skills should be necessary competence of any soldier. The issues related to the existence and establishment of a context, which the conflicts arise in, as well as the issue of impact of cultural factors on military operations should take into account the changes in the today's world. We should also pay attention to asymmetric actions, including terrorism and other types of conflicts, which are definitely different from the war in the classic sense of the word ${ }^{32}$.

\section{BIBLIOGRAPHY}

1. W. Anioz, Procesy globalizacyjne we wspótczesnym świecie, [in:] K.A. Wojtaszczyk, W. Jakubowski (ed.), Społeczeństwo ipolityka. Podstawy nauk politycznych, Wydawnictwo Oficyna Wydawnicza ASPRA JR, Warszawa 2005.

2. Z. BAumann, Nacjonalizm, Sic!, Warszawa 2003.

3. А. Вıкошsкi (red.), Globalizacja gospodarki a ochrona środowiska, Szkoła Główna Handlowa, Warszawa 2002.

4. W. J. BurszTA, Świat jako więzienie kultury, Warszawa 2008.

5. A. Czupryński, L. Elak, H. Schreiber, Bezpieczeństwo dla rozwoju. Komunikacja międzykulturowa w operacjach reagowania kryzysowego, Akademia Obrony Narodowej, Warszawa 2012.

6. L. Gawor, Katastrofizm $w$ życiu cywilizacji narodowych wedlug Zygmunta Wasilewskiego, [in:] A. Żuk (ed.), Konflikt $i$ walka, Lublin 1996.

7. M. Glenny, Carnage in Bosnia, for Starters, "New York Times", 29.07.1993.

8. R. JakubCZaK, J. Flis (ed.), Bezpieczeństwo narodowe Polski w XXI wieku. Wyzwania $i$ strategie, Bellona, Warszawa 2006.

9. Ł. KAMIEŃsKi, Technologia i wojna przyszłości, Wydawnictwo Uniwersytetu Jagiellońskiego, Kraków 2009.

10. J. Keegan, Historia wojen, Warszawa 1998 (Keegan, A History of Warfare, 1994).

11. F. Koneczny, Prawa dziejowe, Londyn 1982 (History laws (and bonus) German byzaninism, Towarzystwo im. Romana Dmowskiego, London 1982).

12. E. KośNı́KI, Człowiek wobec procesów globalizacyjnych, [in:] Z. Hull, W. Tulibacki (ed.), Człowiek wobec świata, Polskie Towarzystwo Filozoficzne, Olsztyn 1996.

13. K. KUCIŃsKi, Gospodarka globalna, Wydawnictwo KURPISZ, Poznań 2000.

14. Z. Kuderowicz, Polska filozofia pokoju. Historia idei pokoju w kulturze polskiej do 1939 roku, Warszawa 1992.

15. U. Kusio, Globalizacja jako imperatyw zmiany na skali wartości rdzennych, [in:] A. Maksymowicz (ed.), Moralne dylematy Polaków w ponowoczesności, Zakład Wydawniczy NOMOS, Kraków 2009.

16. D. Матsumoto, L. Jung, Psychologia międzykulturowa, GWP, Gdańsk 2007 (Culture and Subjective Well-being, MIT Press, 2000).

${ }^{32}$ Cf. Ibidem, pp. 44-97. 
17. M. Mcluhan, The Gutenberg galaxy: the making of typographic man, University of Toronto Press, Toronto 1965.

18. K. MoJzes, Yugoslavian Inferno, "New York Times" 17.09.1992.

19. J. Norberg, Spór o globalizację. Kto zyskuje, kto traci, ile i dlaczego, Wydawnictwo Fijorr Publishing, Warszawa 2006 (In Defense of Global Capitalism, Cato Institute 2003).

20. M. Pawlak, Czynniki determinujące działania militarne wśrodowisku zróżnicowanym kulturowo, doctoral dissertation, promoter M. Wrzosek, Akademia Obrony Narodowej, Warszawa 2013.

21. R. Rosa, L. Wyszczelski, Wojna i pokój w polskiej myśli społecznej i wojskowej, Warszawa 1996.

22. D. Strasburger, Zasady sztuki wojennej, Warszawa 1996.

23. Szanse i zagrożenia rozwojowe $w$ warunkach społeczeństwa informacyjnego, collective work by the team of authors: P. Sienkiewicz, T. Jemioło, L. Zacher, M. Jóźwiak, H. Świeboda, Akademia Obrony Narodowej, Warszawa 2001.

24. T. Szczurek, Konflikty zbrojne. Problematyka filozoficzno-moralna, Wydawnictwo WAT, Warszawa 2009.

25. T. SzCZURek, Od deskrypcji do antycypacji wykorzystania potencjatu militarnego w ksztaltowaniu bezpieczeństwa nowoczesnych wspólnot państwowych wobec rozwoju zagrożeń niemilitarnych, Wydawnictwo WAT, Warszawa 2012.

26. J. Świniarski, Przemiany myślenia o wojnie i wojsku, [in:] „Wojsko i Wychowanie” 1998, Issue 7.

27. J. Świniarski, Zastosowanie megatrendów cywilizacji, wiedzy i informacji w etyce biznesu, [in:] J. Jaroń, Ekofilozofia, bioetyka, etyka biznesu. Aktualne problemy współczesności, Wydawnictwo Akademii Podlaskiej, Siedlce 2004.

28. F. ZnANIECKI, Nauka o kulturze, Warszawa 1971.

\section{KULTUROWE ASPEKTY KONFLIKTÓW ZBROJNYCH}

Streszczenie: $\mathrm{W}$ artykule przedstawiono problematykę prowadzenia operacji zbrojnych w kontekście uwarunkowań kulturowych, $\mathrm{z}$ istotnym znaczeniem dla przebiegu działań militarnych. Pomimo globalizacji, która - jak się zdaje - zaciera wiele różnic kulturowych, one wciąż występują. Często też się pogłębiają. Na tę skomplikowaną sytuację nakładają się konflikty interesów różnych podmiotów państwowych i niepaństwowych oraz grup społecznych. W taki obraz rzeczywistości wpisuje się zjawisko wojny, obecne od początków ludzkiej cywilizacji. Należy zaznaczyć, że wśród licznych przyczyn wojen istotne miejsce zajmują różnice kulturowe. Nierzadko rejon prowadzenia operacji wojskowej jest obcy kulturowo przynajmniej dla jednej ze stron konfliktu. Operacje prowadzone są przez siły międzynarodowe $\mathrm{w}$ różnych rejonach świata, a kontyngent wojskowy operuje nierzadko w środowisku obcym kulturowo. Są to szczególnie skomplikowane zagadnienia, których nie sposób wyjaśnić jednoznacznie, stąd w artykule podjęto jedynie próbę diagnozy najistotniejszych problemów bez wskazywania konkretnych rozwiązań. Zwrócono uwagę na czynniki kulturowe wpływające na źródła konfliktów i ich przebieg oraz na kulturowy kształt środowiska prowadzenia operacji militarnych. Wśród globalnych zjawisk determinujących przebieg przyszłych konfliktów zbrojnych wskazano na kulturowe przekształcanie się społeczeństw i towarzyszące temu napięcia, migracje, komunikację masową i technologie informatyczne oraz odradzanie się religii i nacjonalizmów. Nie pominięto też uwarunkowań lokalnych, w tym aspektów społecznych, politycznych, organizacyjnych oraz kwestii akceptacji odrębności przez strony konfliktu.

Słowa kluczowe: kultura, globalizacja, konflikty zbrojne, operacje wojskowe, wojna. 